\title{
Influence of Phenformin and Metformin on Exercise Induced Lactataemia in Patients with Diabetes Mellitus
}

\author{
P. Björntorp ${ }^{1}$, S. Carlström², S. E. Fagerberg ${ }^{3}$, L. S. Hermann ${ }^{1}$, A. G. L. Holm¹ ${ }^{1}$, B. Scherstén ${ }^{2}$ and J. Östman \\ 1 Department of Medicine I, Sahlgrenska Hospital, Gothenburg, ${ }^{2}$ Department of Medicine, Lund University Hospital, Lund, \\ ${ }^{3}$ Department of Medicine, Örebro Regional Hospital, Örebro, and ${ }^{4}$ Department of Medicine, Huddinge University Hospital, \\ Stockholm, Sweden
}

Summary. The effect of long-term treatment with phenformin and metformin respectively on blood lactate concentrations in relation to submaximal muscular exercise has been examined in 21 maturity-onset diabetics, using a cross-over method. At similar degrees of diabetic control the mean blood lactate concentration during exercise and shortly thereafter was significantly higher when the patients had received phenformin.

The mean fasting lactate concentration was $1.07 \mathrm{mmol} / 1$ with phenformin and $1.03 \mathrm{mmol} / 1$ with metformin and the peak concentration was $2.56 \mathrm{mmol} / 1$ and $2.19 \mathrm{mmol} / 1$ respectively. The mean fasting blood glucose concentration before the exercise was $11.2 \mathrm{mmol} / 1$ with phenformin and $11.3 \mathrm{mmol} / 1$ with metformin; the glucose output in the urine during the preceding 24 hours was $93 \mathrm{mmol}$ and $105 \mathrm{mmol}$ respectively. The mean work load during exercise was 60 watts.

Key words: Phenformin, metformin, exercise, lactataemia, diabetes mellitus.

Lactic acidosis has occurred in many patients treated with phenformin, but only occasionally in patients treated with metformin [1-3]. The metformin-associated cases in particular occurred when renal function was decreased [4]. Buformin has also been associated with lactic acidosis [5].

Earlier investigations on lactate metabolism under different experimental conditions in humans have shown that phenformin may contribute to hyperlactataemina [3]. Comparative studies [6-13] indicate that metformin has less effect on lactate metabolism than phenformin for the same hypoglycaemic effect.
This investigation was performed to determine whether a difference could be found between the effects of phenformin and metformin upon the elevation in blood lactate concentration induced by muscular exercise in diabetic patients on long-term biguanide therapy.

\section{Patients and Methods}

\section{Patients}

The investigation was carried out on 21 maturity-onset diabetics 11 men and 10 women - from four different outpatient clinics. The patients were on long-term therapy with biguanides, 13 in combination with sulphonylureas. Characteristics of the patients are shown in Table 1 . The mean age was 58 years (range $40-69$ years). $80 \%$ of the patients were overweight (ideal body weight $>110 \%$ ). Eight patients had hypertension and received different antihypertensive treatment. They continued to receive the same drugs throughout. All patients had normal serum creatinine concentrations and there was no evidence of liver disease.

Table 1. Characteristics of the patients

\begin{tabular}{|c|c|c|}
\hline & Mean & Range \\
\hline Age & 58 years & $40-69$ years \\
\hline Weight & $74 \mathrm{~kg}$ & $49-91 \mathrm{~kg}$ \\
\hline$\%$ Ideal body weight & $119^{\circ}$ & $77-150^{\circ}$ \\
\hline Serum-creatinine & $90 \mu \mathrm{mol} / 1$ & $75-120 \mu \mathrm{mol} / 1$ \\
\hline Diabetes duration & 7 years & $1-14$ years \\
\hline $\begin{array}{l}\text { Duration of } \\
\text { phenformin treatment }\end{array}$ & 42 months & $8-96$ months \\
\hline $\begin{array}{l}\text { Duration of } \\
\text { metformin treatment }\end{array}$ & 17 months & $1-36$ months \\
\hline $\begin{array}{l}\text { Interval between } \\
\text { examinations }\end{array}$ & 4 weeks & 2-4 weeks \\
\hline Daily dose & & \\
\hline $\begin{array}{l}\text { phenformin } \\
\text { Daily dose }\end{array}$ & $90 \mathrm{mg}$ & $50-100 \mathrm{mg}$ \\
\hline metformin & $1.6 \mathrm{~g}$ & $1.5-3.0 \mathrm{~g}$ \\
\hline Work load & 60 watts & $20-100$ watts \\
\hline
\end{tabular}


Table 2. Mean blood glucose concentration ( \pm SEM) and mean glycosuria ( \pm SEM) after phenformin and metformin respectively

\begin{tabular}{|c|c|c|c|c|}
\hline $\begin{array}{l}\text { Diabetic } \\
\text { control }\end{array}$ & & $\begin{array}{l}\text { group } \\
\mathrm{I}+\mathrm{II}\end{array}$ & $\begin{array}{l}\text { group } \\
\text { I }\end{array}$ & $\begin{array}{l}\text { group } \\
\text { II }\end{array}$ \\
\hline $\begin{array}{l}\text { Blood } \\
\text { glucose } \\
\mathrm{mmol} / 1\end{array}$ & $\begin{array}{l}\text { Phenformin } \\
\text { Metformin } \\
\text { P }\end{array}$ & $\begin{array}{c}11.2 \pm 0.8 \\
11.3 \pm 0.8 \\
\text { N.S. }\end{array}$ & $\begin{array}{c}11.3 \pm 1.0 \\
11.4 \pm 1.3 \\
\text { N.S. }\end{array}$ & $\begin{array}{c}11.0 \pm 1.3 \\
11.2 \pm 1.0 \\
\text { N.S. }\end{array}$ \\
\hline $\begin{array}{l}\text { Urine } \\
\text { glucose } \\
\text { mmol } / 24 \mathrm{~h}\end{array}$ & $\begin{array}{l}\text { Phenformin } \\
\text { Metformin } \\
\text { P }\end{array}$ & $\begin{array}{c}93 \pm 30 \\
105 \pm 32 \\
\text { N.S. }\end{array}$ & $\begin{array}{c}102 \pm 47 \\
98 \pm 43 \\
\text { N.S. }\end{array}$ & $\begin{array}{c}84 \pm 39 \\
112 \pm 49 \\
\text { N.S. }\end{array}$ \\
\hline
\end{tabular}

Group I: patients switching from phenformin to metformin Group II: patients switching from metformin to phenformin Conversion: SI to traditional units - Glucose: $1 \mathrm{mmol} / 1 \approx 18 \mathrm{mg} /$ $100 \mathrm{ml}$

Table 3. Mean basal and peak blood lactate concentrations $( \pm \mathrm{SEM})$

\begin{tabular}{|c|c|c|c|c|}
\hline \multicolumn{2}{|c|}{$\begin{array}{l}\text { Blood lactate } \\
\mathrm{mmol} / \mathrm{l}\end{array}$} & $\begin{array}{l}\text { group } \\
\mathrm{I}+\mathrm{II}\end{array}$ & $\begin{array}{l}\text { group } \\
\text { I }\end{array}$ & $\begin{array}{l}\text { group } \\
\text { II }\end{array}$ \\
\hline Basal & $\begin{array}{l}\text { Phenformin } \\
\text { Metformin } \\
\text { p }\end{array}$ & $\begin{array}{c}1.07 \pm 0.06 \\
1.03 \pm 0.07 \\
\text { N.S }\end{array}$ & $\begin{array}{c}1.00 \pm 0.09 \\
1.05 \pm 0.10 \\
\text { N.S. }\end{array}$ & $\begin{array}{c}1.14 \pm 0.08 \\
1.01 \pm 0.07 \\
\text { N.S. }\end{array}$ \\
\hline Peak & $\begin{array}{l}\text { Phenformin } \\
\text { Metformin } \\
\text { P }\end{array}$ & $\begin{array}{c}2.56 \pm 0.25 \\
2.19 \pm 0.25 \\
<0.10\end{array}$ & $\begin{array}{c}2.76 \pm 0.23 \\
2.38 \pm 0.38 \\
\text { N.S. }\end{array}$ & $\begin{array}{c}2.33 \pm 0.46 \\
2.00 \pm 0.26 \\
\text { N.S. }\end{array}$ \\
\hline
\end{tabular}

Group I: patients switching from phenformin to metformin Group II: patients switching from metformin to phenformin Conversion: SI to traditional units - Lactate: $1 \mathrm{mmol} / \mathrm{I} \approx 9 \mathrm{mg} /$ $100 \mathrm{ml}$

The mean duration of diabetes was seven years (range 1-14 years). Eleven patients entered the study on long-term therapy with phenformin (group I) and 10 on metformin (group II). The mean duration of biguanide therapy was 17 months for metformin and 42 months for phenformin.

\section{Experimental Design}

Patients on long-term treatment with a biguanide were selected for the study. An exercise test was performed and repeated after changing to the other biguanide, with an interval of about four weeks between the two test periods (Table 1).

The patients were examined after an overnight fast, one hour after their morning dose of the drug. The exercise was performed on a stationary bicycie at submaximal work load (Table 1). The patient's individual work load varied, but was identical during the two investigations.

The doses of the two drugs used (Table 1) were $50-100 \mathrm{mg}$ phenformin daily (Dibein Retard ${ }^{\circledR}$ ) and $1.5-3.0 \mathrm{~g}$ metformin (Glucophage ${ }^{\circledR}$ ). The dose was adjusted before the second exercise test to give the same degree of diabetic control as before the first test (Table 2). The dose that was arrived at after the switch-over was the same, whether the patients started with phenformin or metformin.

Blood samples for lactate determinations were collected without stasis from an antecubital vein through an indwelling catheter.
Basal values were recorded 15, 10 and five minutes before the start of the exercise and at time zero. Samples were then collected after five, 10 and 15 minutes' exercise and also at five, 10 and 15 minutes after cessation of work (Fig. 1). Before the exercise blood samples were taken for determination of the fasting glucose concentration. Urine was collected during the preceding 24 hours to determine the degree of glycosuria (Table 2).

\section{Analytical Procedures}

Lactate concentrations were determined with an enzymatic method (Boehringer Mannheim) in blood deproteinized immediately with perchloric acid $0.6 \mathrm{~mol} / \mathrm{h}$ and stored at $4^{\circ} \mathrm{C}$ before analysis. All determinations were made in duplicate. Blood and urine glucose concentrations were determined by the glucose oxidase method.

\section{Statistical Methods}

Student's t-test for paired samples was used. Results are given as means \pm standard error of the mean (SEM).

\section{Results}

An analysis of the results in group I and II separately showed that phenformin and metformin respectively had a similar effect on blood lactate levels in the two groups. Therefore these groups were then analysed jointly and the cumulated data presented. Basal and peak values are shown in Table 3 .

The basal blood lactate values for all patients were within the normal range and no difference was found between phenformin and metformin treatment (Fig. 1). After 10 minutes of exercise a significant difference was found, which reappeared 10 and 15 minutes after the exercise. During this period the mean blood lactate concentration was significantly higher when the patient received phenformin $(P<$ $0.05)$. The difference was of borderline significance at the end of the exercise and five minutes thereafter $(\mathrm{P}<0.10)$. As a whole the profile of the two curves was similar - phenformin $30 \%$ above metformin.

The cumulated data presented do not include the data from one patient originally in group II, who showed a continous increase in blood lactate after the first exercise, while all others showed a normal decrease. This patient is discussed separately.

\section{Discussion}

Since considerable variation in blood lactate concentration following exercise is known to exist [1], the patients were used as their own controls in a crossover fashion. Submaximal work load, sufficient to produce an adequate lactate increase, was used. Although the individual work loads differed consid- 


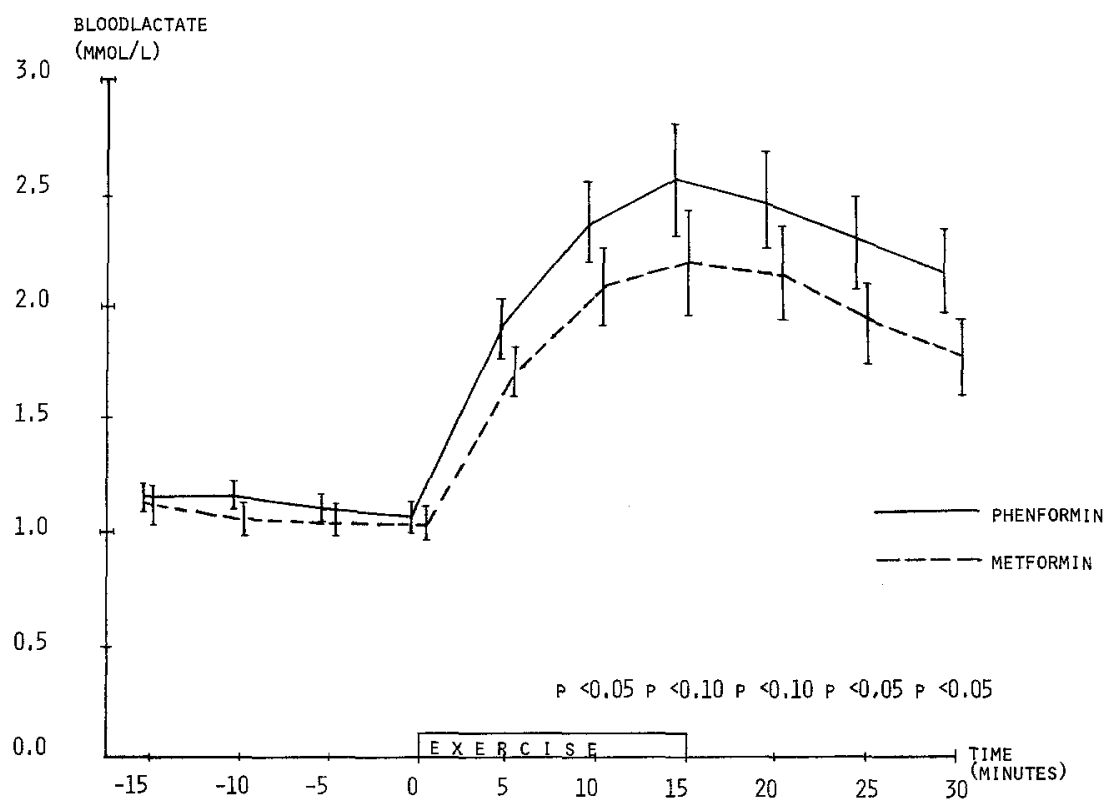

Fig. 1. Mean blood lactate concentrations $( \pm S E M)$ in relation to muscular exercise after phenformin and metformin respectively ( $\mathrm{P}$-values: see text)

erably (Table 1 ), the variation in blood lactate rises was moderate.

One patient showed a divergent result, which could not be explained. The patient had recently suffered from pulmonary tuberculosis and a very high pulse rate was recorded at the first exercise test. However, even if this patient were included in the total material a difference between phenformin and metformin remained.

The influence of phenformin on lactate metabolism in relation to muscular exercise has been examined previously in normal subjects as well as diabetics (14-19) and the results of these studies were summarized by Hermann [3] and Cohen and Woods [1]. It is difficult to draw general conclusions from these studies because of the variability of lactate concentrations and dosage schedules, but in some of the studies phenformin was found to be a contributing factor in producing hyperlactataemia $[15,18,19]$.

With the exception of one study [19], previous investigations of biguanides and lactate metabolism in relation to muscular exercise have been performed in patients on short-term therapy. Our patients entered the study on long-term therapy. The treatment period after cross-over to the second drug was shorter than the treatment period before the first exercise test. However, half of the patients were on phenformin at the first examination and the other half on metformin, thus making valid comparison possible.

Phillips et al. [13] compared the effects of phenformin and metformin in four normal subjects and four obese maturity-onset diabetics, during and after lactate infusion and after submaximal exercise. The study was based on a one compartment model and lactate half lives were calculated. In the diabetic patients the lactate half lives were longer than in the normal subjects. Both biguanides increased the half lives, but metformin had significantly less effect than phenformin.

Some other comparative studies have been reported with varying results. Alexander et al. [6] found that both phenformin and metformin caused hyperlactataemia during a glucose load, compared with diet alone. The effect was more pronounced with phenformin. With a fructose load, similar results have been reported in diabetics [8], whereas no difference was found in healthy subjects [7].

Blood lactate concentrations at rest have also been compared in diabetics receiving different antidiabetic therapy. Luyckx et al. [11] found that wellcontrolled diabetics on phenformin therapy had significantly higher fasting blood lactate concentrations than diabetics treated with metformin. The difference was even greater in patients with poor diabetic control and patients with vascular complications. Debry et al. [8] found that metformin therapy did not affect fasting blood lactate concentrations and in two other studies $[9,10]$ neither phenformin nor metformin caused a significant change in fasting blood lactate levels.

In a recent study Nattrass et al. [12] compared the effect of treatment for one month with phenformin, metformin and glibenclamide respectively on metabolic rhythms in six maturity-onset diabetics, using a cross-over method, but without a control period. The mean fasting blood lactate concentration was the same during the different treatment regimes, 
but the mean diurnal 12 hour lactate concentration was elevated during therapy with phenformin and metformin compared with glibenclamide and significantly more with phenformin than with metformin at comparable blood glucose levels.

The difference between the effect of phenformin and metformin on lactate metabolism is in accordance with the clinical fact that lactic acidosis has occurred in many patients treated with phenformin, but only occasionally in patients treated with metformin $[1-4]$. The metformin cases have particularly been associated with decreased renal function [4]. The reason for this difference could be the different pharmacokinetic properties of the two drugs. Phenformin has a greater tendency to fixation to cell membranes [20] and it is also partially metabolized and concentrated in the liver, while metformin is excreted unchanged in the urine $[1,2,21]$.

Addendum. After revision of this manuscript two comparative studies of the effect of biguanides on lactate metabolism have been published. Czyzyk et al. [22] found that short-term biguanide therapy had a significant effect in healthy subjects during ethanol and fructose loading as well as submaximal exercise. The differences between the three biguanides used were minimal, but the fasting blood lactate levels were significantly higher after phenformin than after buformin or metformin. Waters et al. [23] found that the mean post-prandial blood lactate level in maturity-onset diabetics was significantly higher during phenformin and metformin therapy than with diet alone. When given alone phenformin had a significantly greater effect than metformin, but not when given in combination with a sulphonylurea. The mean blood lactate was raised in $63 \%$ patients on phenformin alone, but only in $22 \%$ patients on metformin alone.

These studies demonstrate an effect of biguanides on lactate metabolism and indicate that metformin has less effect than phenformin.

\section{References}

1. Cohen, R. D., Woods, H. F.: Clinical and biochemical aspects of lactic acidosis. Oxford: Blackwell Scientific Publications 1976

2. Daubresse, J. C., Luyckx, A., Lefebvre, P.: Acidose lactique et thérapeutique par biguanides. Méd. et Hyg. 11.58, 1165-1168 (1975)

3. Hermann, L. S.: Biguanides and lactate metabolism. A Review. Dan. Med. Bull. 20, 65-79 (1973)

4. Assan, R., Heuclin, Ch., Ganeval, D., Bismuth, Ch., George, J., Girard, J. R.: Metformin-induced lactic acidosis in the presence of acute renal failure. Diabetologia 13, 211-217 (1977)

5. Wittmann, P., Haslbeck, M., Bachmann, W., Mehnert, H.: Laktatacidosen bei Diabetikern unter Biguanidbehandlung. Dtsch. Med. Wochenschr. 102, 5-10 (1977)

6. Alexander, W. D., Marples, J.: Biguanides and lactic acidosis. Lancet 1977 I, 191-192

7. Czyzyk, A., Lao, B., Bartosiewicz, W., Szezepanik, Z.: Acidose lactique au cours du traitement du diabète par différents dérivés de biguanide. Journ. Annu. Diabetol. Hôtel-Dieu 1973, 277-287

8. Debry, G., Laurent, J.: Lactic acidosis and diabetes mellitus. Helv. Med. Acta 35, 433-447 (1969/70)

9. Jaillard, J.: Étude comparative des variations de la lactacidémia sous metformine et phenformine. Via Médicale 36, 4503-4506 (1974)

10. Lao, B., Okninski, W.: Influence of biguanide derivatives on blood lactic acid level in diabetic patients. Pol. Arch. Med. Wewn. 47, 675-678 (1971)

11. Luyckx, A., Daubresse, J. C., Carpentier, J. L., Lefebvre, P.: La place des biguanides dans le traitement du diabète sucré. Journ. Annu. Diabetol. Hôtel-Dieu 1974, 129-150

12. Nattrass, M., Todd, P. G., Hinks, L., Lloyd, B., Alberti, K. G. M. M.: Comparative effects of phenformin, metformin and glibenclamide on metabolic rhythms in maturity-onset diabetics. Diabetologia 13, 145-152 (1977)

13. Philipps, P. J., Thomas, D. W., Harding, P. E.: Biguanides and lactic acidosis. Br. Med. J. 1977 I, 234

14. Güttler, F., Petersen, F. B., Kjeldsen, K.: The influence of phenformin on blood lactic acid in normal and diabetic subjects during exercise. Diabetes 12, 420-423 (1963)

15. Hermann, L.S., Nathan, E., Ebbesen, I.: The influence of phenformin on lactate metabolism in diabetic patients in relation to hypoxia and exercise. Acta Med. Scand. 194, 111-116 (1973)

16. Miller, M.: Side effects of the biguanide therapy and the problem of lactic acidosis. In: K. Oberdisse, H. Daweke, G, Michael (ed.): 2. Internationales Biguanid Symposium. Stuttgart: Georg Thieme 1968

17. Shepardson, C. R., Christopher, T. G., Miller, M.: The effect of phenethylbiguanide on blood lactate levels following exercise. J. Lab. Clin. Med. 60, 1018 (1962)

18. Sølvsteen, P., Hansen, F. L., Ebbesen, I., Iversen, M.: Virkningen af fenformin på mælkesyreproduktionen under hypoksi og muskelarbejde. Ugeskr. Læger 130, 812-815 (1968)

19. Walker, R. S., Linton, A.L., Thomson, W. S. T.: Mode of action and side effects of phenformin hydrochloride. Br. Med. J. 1960 II, 1567-1569

20. Schäfer, G.: Commentary on the mechanism of action of hypoglycemia-producing biguanides. A reevaluation and a molecular therapy. Biochem. Pharmacol. 25, 2005-2014 (1976)

21. Berger, W., Göschke, H., Ohnhaus, E.: Problèmes d'actualité concernant le mécanisme d'action des biguanides. Journ. Annu. Diabetol. Hôtel-Dieu 1975, 239-258

22. Czyzyk, A., Lao, B., Bartosiewicz, W., Szczepanik, Z., Ortowska, K.: The effect of short-term administration of antidiabetic biguanide derivatives on the blood lactate levels in healthy subjects. Diabetologia 14, 89-94 (1978)

23. Waters, A. K., Morgan, D. B., Wales, J. K.: Blood lactate and pyruvate levels in diabetic patients treated with biguanides with and without sulphonylureas. Diabetologia 14, 95-98 (1978)

Received: November 14, 1977,

and in revised form: March 14, 1978

Dr. L. S. Hermann

Domarevägen 41

S-433 00 Partille

Sweden 